\title{
Spatial-Temporal Dynamics of Vegetation Cover in a Diversity Hotspot for the Conservation of Brazilian Cerrado
}

\author{
Nathan C. Fonsêca ${ }^{1}$, Giselle L. Moreira ${ }^{1}$, José Nailson B. Santos ${ }^{1}$, Marília Isabelle O. da Silva ${ }^{1}$, \\ Máida Cynthia D. de Lima ${ }^{2}$, Ana Jéssica S. Barbosa ${ }^{3}$, Jéssica Stéfane A. Cunha ${ }^{1}$, Diogo José O. Pimentel ${ }^{1}$, \\ Flávio Cipriano de A. do Carmo ${ }^{4} \&$ Felipe S. Amorim ${ }^{5}$ \\ ${ }^{1}$ Forest Science Postgraduate Programme, Federal Rural University of Pernambuco, Recife, PE, Brazil \\ ${ }^{2}$ Postgraduate in Agronomy, State University of Southwest of Bahia, Vitória da Conquista, Bahia, Brazil \\ ${ }^{3}$ Postgraduate in Agronomy, Federal University of Paraiba, Areia, Paraíba, Brazil \\ ${ }^{4}$ Department of Forestry Science, Federal University of Campina Grande, Campina Grande, Paraíba, Brazil \\ ${ }^{5}$ Department of Forestry Science, Federal University of Piauí, Bom Jesus, Piauí, Brazil
}

Correspondence: Nathan C. Fonsêca, Forest Science Postgraduate Programme, Federal Rural University of Pernambuco, Rua Dom Manoel de Medeiros, s/n, Dois Irmãos, Recife, PE, 52.171-900, Brazil. Tel: 55-899-9906-0340. E-mail: nathanflorestal@hotmail.com

$\begin{array}{lcc}\text { Received: June 16, } 2019 & \text { Accepted: July 21, } 2019 & \text { Online Published: September 15, } 2019 \\ \text { doi:10.5539/jas.v11n15p200 } & \text { URL: https://doi.org/10.5539/jas.v11n15p200 }\end{array}$

\begin{abstract}
This work investigates the spatial-temporal dynamics of land use and vegetation covers in a conservation area of Cerrado, in the county of Currais, Piauí, in which the economy depends on large agricultural projects. We used maps of a 32-year time series (1985 to 2017) of land use and cover provided by the Brazilian Annual Land Use and Land Cover Mapping Project (MapBiomas). We assessed six classes of land uses and vegetation covers: forest, savanna, grassland, agriculture/pasture, non-vegetated area, and water bodies. There was a fast increase in pressure on natural ecosystems from 1985 and 2017, primarily from 2000. The land use for agriculture and pasture increased from $0.26 \%$ (726.93 ha) in 2000 to $16 \%(50,772.63 \mathrm{ha})$ in 2017 . During this period, the native vegetation decreased $15.90 \%$, with savannas suffering the largest loss in hectares of vegetation (41,663.73 ha), followed by the forests $(9,837.35 \mathrm{ha})$. The grassland cover, non-vegetated area, and water bodies remained unchanged. These results provide essential information for decision making and can be used to guide public policies for the conservation, monitoring, and sustainable management of remnant vegetation areas.
\end{abstract}

Keywords: Agricultural industry, deforestation, natural ecosystems, geoprocessing, time series

\section{Introduction}

The Cerrado biome comprises a critical area for conservation of global biological diversity (hotspot) due to its high species richness and strong anthropic pressure (Mittermeier et al., 2011; Sloan et al., 2014). Its ecosystems have a high number of endemic species, which are threatened continuously by anthropogenic processes that already modified more than $70 \%$ of original vegetation over the years (Reydon \& Monteiro, 2009). As a hotspot, the Cerrado should, in practice, be regarded as a priority area for environmental conservation. However, the use and occupation of this biome for the development of agribusiness have been a leading factor altering the natural landscape, converting native vegetation areas into agricultural lands (Silva et al., 2014; Santos et al., 2017).

The incorporation of new areas for agriculture aims to meet the demand for food. However, it provokes large scale environmental impacts, putting natural resources, biodiversity, and ecosystem services at risks (Santos et al., 2017). In the state of Piauí, northeastern Brazil, the Cerrado comprises an area of 8.5 million hectares, about $70 \%$ of the state's territory. This area has been intensively exploited to agriculture since the $1970 \mathrm{~s}$ and $1980 \mathrm{~s}$, with intensification in 1990 through the implementation of large projects (Aguiar \& Monteiro, 2005).

The continuous occupation of Cerrado lands in Piauí occurs for several reasons, including the exhaustion of soils in other regions of Brazil, the flat topography, which favors the mechanization, the climate suitability for cultivating grain crops, lower land values, and tax incentives (Borghi et al., 2014). In this perspective, the southern region of Piauí is considered one of the last agricultural frontiers within the Cerrado biome (Botrel et al., 
2015). This area includes the Currais county, which in the last three decades has undergone an intensive process of occupation of Cerrado as a consequence of agricultural activities. Thus, the knowledge about areas occupied by agriculture and data on landscape changes over time and space become essential tools for legislators and planners of the use of natural resources.

Remote sensing and geoprocessing techniques became indispensable tools for monitoring the dynamics of land use and vegetation cover (Vaeza et al., 2010; Silva et al., 2014). In northeastern Brazil, several studies have been carried out to detect trends in changes of landscapes both at local and regional scales (Benedetti et al., 2013, Silva et al., 2014, França et al., 2018). On the other hand, little studies were carried out in southern Piauí, where large areas of relevant interest for the conservation of the Cerrado persist. Thus, the present work aimed to analyze the spatial-temporal dynamics of land use and vegetation cover to provide information for public policies of conservation, preservation, and sustainable management of natural resources in a biodiversity hotspot of Cerrado.

\section{Method}

\subsection{Location and Characterization of Study Areas}

The work was carried out in the Currais county, in center-south of the state of Piauí, under coordinates $44^{\circ} 18^{\prime}-45^{\circ} 05^{\prime} \mathrm{W}$ and $8^{\circ} 26^{\prime}-9^{\circ} 02^{\prime} \mathrm{S}$. The county is $640 \mathrm{~km}$ from capital Teresina and comprises an area of $3,156.6 \mathrm{~km}^{2}$, with the following bordering counties: Palmeira do Piauí and Baixa Grande do Ribeiro to the north, Bom Jesus to the South, Santa Luz and Palmeira do Piauí to the East, and Baixa Grande do Ribeiro to the West. Also, Currais lies in a region with a predominance of biodiversity hotspots of Cerrado biome, comprising priority areas for conservation according to Decree No. 5,092 (Brazil, 2004). Large agricultural projects maintain the economic activity of Currais, above all, the soybean cultivation (Figure 1).

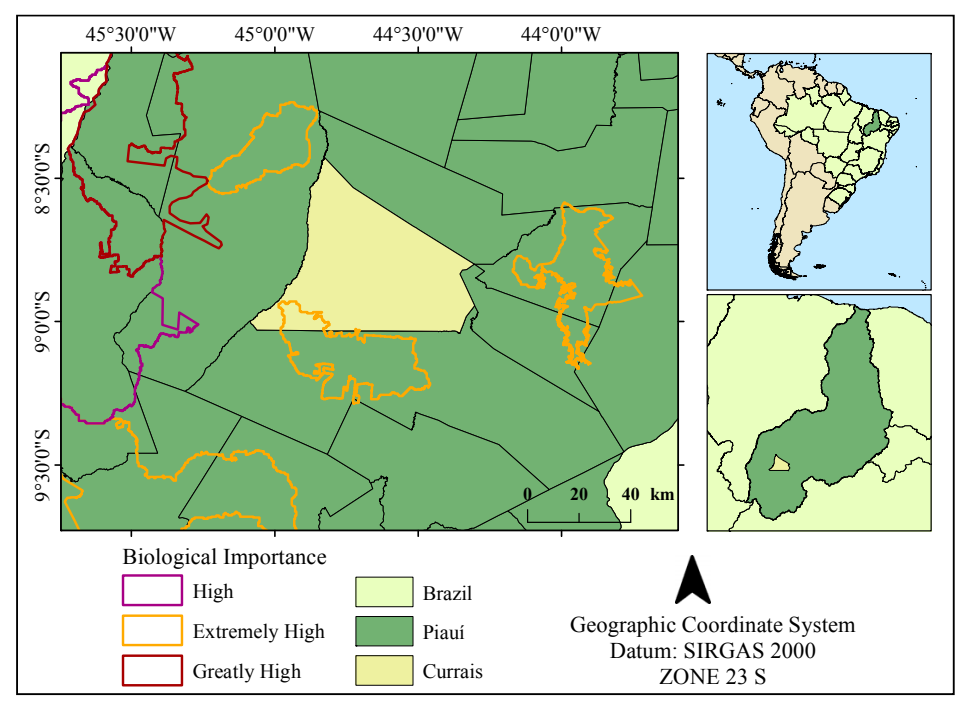

Figure 1. Geographical location of the county of Currais, Piauí, Brazil. The colored polygons on the highlighted map highlight the categories with biological importance for conservation of Cerrado biome in the region (Brasil, 2004)

According to the classification of Köppen, the regional climate is Aw' (hot and semi-humid) with temperatures above $18{ }^{\circ} \mathrm{C}$ (Alvares et al., 2013). The average annual rainfall matches the Continental Equatorial Regime, with annual isohyets around 700 to $1,200 \mathrm{~mm}$ and rainy season extending from November to May, with January, February, and March being the wettest quarter (IBGE, 2000; Pragana et al., 2012). The vegetation covers include formations from two biomes, Cerrado and Caatinga, and, to a lesser extent, in an ecotone area of cerrado-caatinga (Cepro, 1996; Botrel et al., 2015).

\subsection{Data Acquisition and Processing}

Land use and land cover maps (Collection 3) of a 32-year time series (1985 to 2017) were generated and provided free of charge by the Brazilian Annual Land Use and Land Cover Mapping Project (MapBiomas). The frequency of images had amplitude of 5 years, except from 2015 to 2017, in which amplitude of 2 years was 
used. The MapBiomas project aims the mapping and quantifying of land use and coverage of the Brazilian territory in an automated and consistent way. The project brought together interdisciplinary teams to obtain the maps, including specialists in biomes and cross-cutting themes (mining, agriculture, pasture, among others).

The images used by MapBiomas come from Landsat series of satellites (5-TM, 7-ETM+, and 8-OLI), providing data from 1985 to the present year (2019). In the land use and land cover classification procedure, the project used, in collection 3, the Random Forest algorithm including a more robust sampling designed to train the classifier (MapBiomas, 2019). The classification done by the MapBiomas followed the methodological steps described in Figure 2.

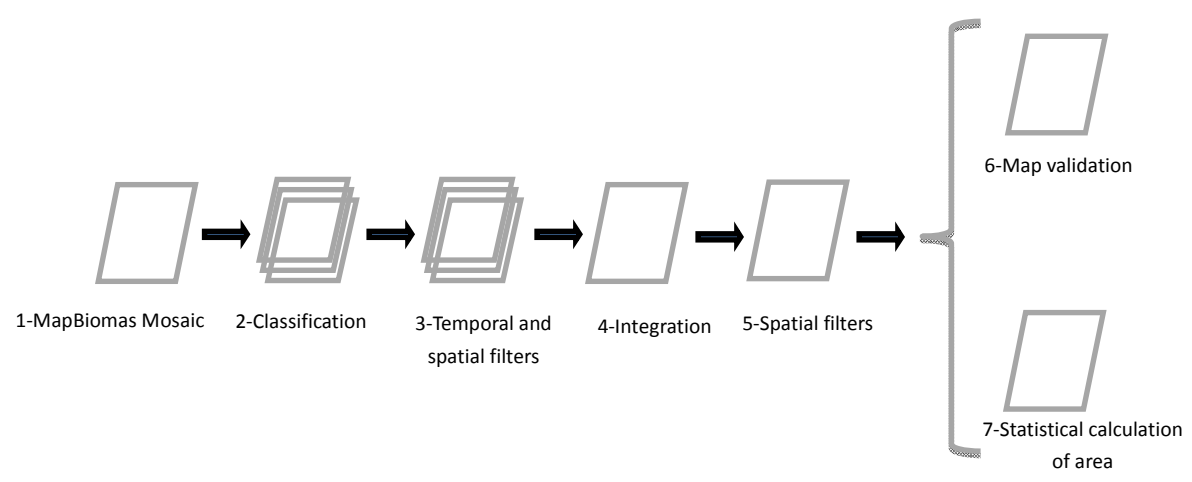

Figure 2. Methodological steps to classify and obtain land use and land cover maps in the county of Currais, Piauí, Brazil

Stage 1. Production of annual Landsat image mosaics based on specific periods to optimize the contrast between land use and land cover classes. At this stage, biomes, transition areas between biomes and transverse themes (i.e., mining, agriculture, pasture, among others) were separated to obtain maps of land use and cover.

Stage 2. The setting of characteristic spectral inputs (training samples) derived from the bands of the Landsat images to carry out the classification by the Random Forest algorithm.

Stage 3. Use of spatial and temporal filters to the maps generated in the previous step with the aim of removing noise from the classification and filling the information gaps caused by clouds.

Stage 4. Integration of land use and land cover maps of each biome and cross-cutting themes, through the hierarchical overlap of each mapped class, according to specific rules of prevalence empirically defined.

Stage 5. Use of spatial filters to remove isolated classes (smaller than half a hectare) and noise resulting from an incorrect record of Landsat data.

Stage 6. Mapping validation based on two approaches: (a) spatial matching analyzes with reference maps according to their availability (b) spatial matching analyzes based on statistical techniques to define sample points based on the extent and number of classes of each biome.

Stage 7. Calculation of the zonal statistics of the classes mapped to different spatial units (biomes, states, and municipalities), including watersheds, rural settlements, and protected areas.

Based on the specificities of the county, only six classes of land use and cover were considered in this study (Table 1). 
Table 1. Classes of land use and land cover used for classification of the county of Currais, Piauí, Brazil

\begin{tabular}{|c|c|}
\hline Classes & Description \\
\hline \multirow{4}{*}{ Forest Formation } & Caatinga \\
\hline & $\begin{array}{l}\text { Types of vegetation with continuous canopy predominance-Forested Steppe-Savannah, and Decidual and } \\
\text { Semi-Decidual Seasonal Forest. }\end{array}$ \\
\hline & Cerrado \\
\hline & Vegetation with a predominance of arboreal species, with continuous canopy formation (Riparian Forest, Gallery \\
\hline \multirow{4}{*}{ Savanna Formation } & 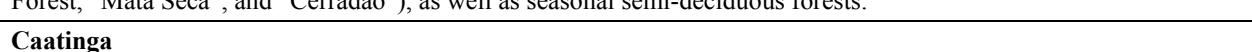 \\
\hline & $\begin{array}{l}\text { Types of vegetation with the predominance of semi-continuous canopy species - Wooded Steppe-Savannah, Wooded } \\
\text { Savannah. }\end{array}$ \\
\hline & Cerrado \\
\hline & $\begin{array}{l}\text { Savanna formations with well delimited arboreal and shrub-herbaceous strata (Cerrado in strict sense, Dense Cerrado, } \\
\text { Typical Cerrado, Sparse Cerrado, Rocky Cerrado, and Parklands). }\end{array}$ \\
\hline \multirow{4}{*}{ Grassland Formation } & Caatinga \\
\hline & $\begin{array}{l}\text { Vegetation with the predominance of herbaceous species (Steppe-Savannah Park, Gramineous-Woody } \\
\text { Steppe-Savannah, Savannah Park, Gramineous-Woody Savannah) }+ \text { (Flooded areas with a network of interconnected } \\
\text { ponds, and vegetation with the predominance of herbs and shrubs). }\end{array}$ \\
\hline & Cerrado \\
\hline & Grasslands with a predominance of herbaceous stratum (dirty field, clean field, and rocky field). \\
\hline \multirow{4}{*}{ Non-vegetated area } & Urbanized Area \\
\hline & Urbanized areas with a predominance of non-vegetated surfaces, including roads and constructions. \\
\hline & Exposed soil \\
\hline & $\begin{array}{l}\text { Areas with exposed soils or naturally exposed rocks without soil cover, often with partial presence of rock vegetation } \\
\text { and high slope. }\end{array}$ \\
\hline \multirow{4}{*}{ Agriculture/pasture } & Agriculture \\
\hline & Areas predominantly occupied with annual and perennial crops. \\
\hline & Pasture \\
\hline & Natural or planted pasture areas linked to agricultural activity. \\
\hline Water bodies & Rivers, lakes, dams, reservoirs and other bodies of water. \\
\hline
\end{tabular}

Source: MapBiomas (2019).

After obtaining the land use and land cover maps for the time series analyzed, we calculated the statistical data of the areas of each class in the county.

\section{Results and Discussion}

The maps and time series showed an increasing anthropic pressure on the natural ecosystems between 1985 and 2017. The savannah vegetation cover predominated in the last year analyzed, representing $50 \%$ of all the vegetation of the county, followed by the grasslands $(23.80 \%)$, and forests $(10.16 \%)$. The area of agriculture/pasture corresponded to $16 \%$. The non-vegetated area and the water bodies covered less than $1 \%$ of the county and remained unchanged over the years (Figure 3). 


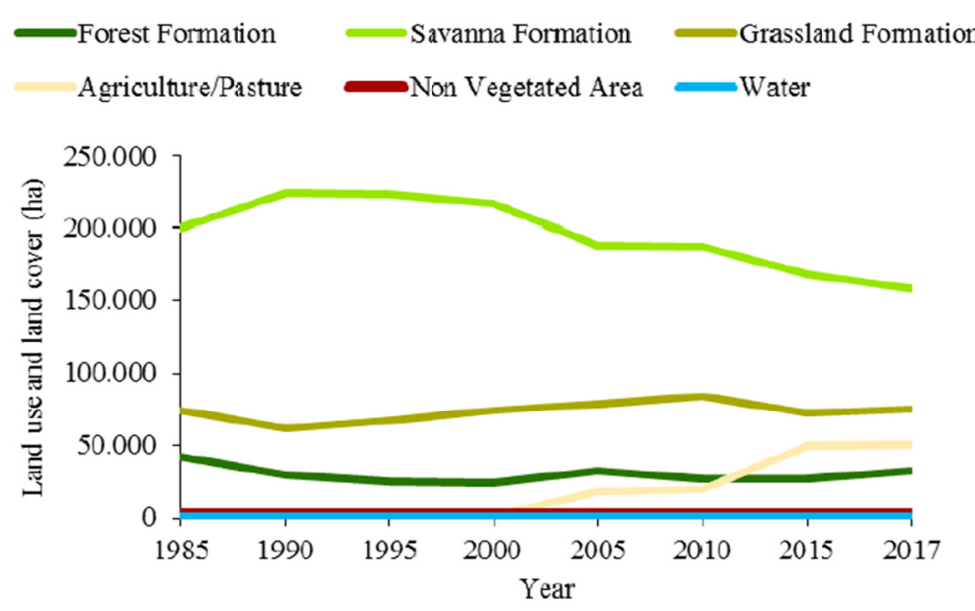

Figure 3. Spatial-temporal analysis of land use and land cover changes in Currais, Piauí, Brazil

From the year 2000, the changes in the natural landscape became more noticeable due to the beginning of use and occupation of lands mainly for agriculture. The expansion of agriculture and pasture increased dramatically, from $0.26 \%$ ( $726.93 \mathrm{ha}$ ) in 2000 to $16 \%(50,772.63 \mathrm{ha})$ in 2017 . Due to this advance, there was a sharp decrease of $15.90 \%$ in native vegetation.

Over the years, natural ecosystems have suffered a fast process of land use and occupation, being intensively exploited for agricultural and livestock purposes. The Cerrado, formed by a complex network of plant formations, such as grasslands, savannas, and forests, is considered a biodiversity hotspot and a priority for conservation (Ribeiro \& Walter, 2008; Mittermeier et al., 2011). However, it is also regarded as an ideal region for the expansion of agriculture (Borghi et al., 2014), which is often carried out intensively and disorderly. The scenario favoring agriculture lead to a significant increase in deforestation in the last 40 years (Silva et al., 2014).

The state of Piauí, with $70 \%$ of its territory covered by Cerrado vegetation, shows great potential for agricultural expansion (Silva et al., 2014), mainly due to its edaphoclimatic characteristics and the geomorphology of the area that favors the agrarian mechanization.

In the state, 24 counties stand out in agricultural production (Santos et al., 2017). Among them, Currais underwent a rapid change in the use and occupation of land in recent years, which has affected the natural landscape (Figure 4). For example, the conversion of the natural vegetation, mainly the savanna, into agricultural areas that occurred from the year 2000. 


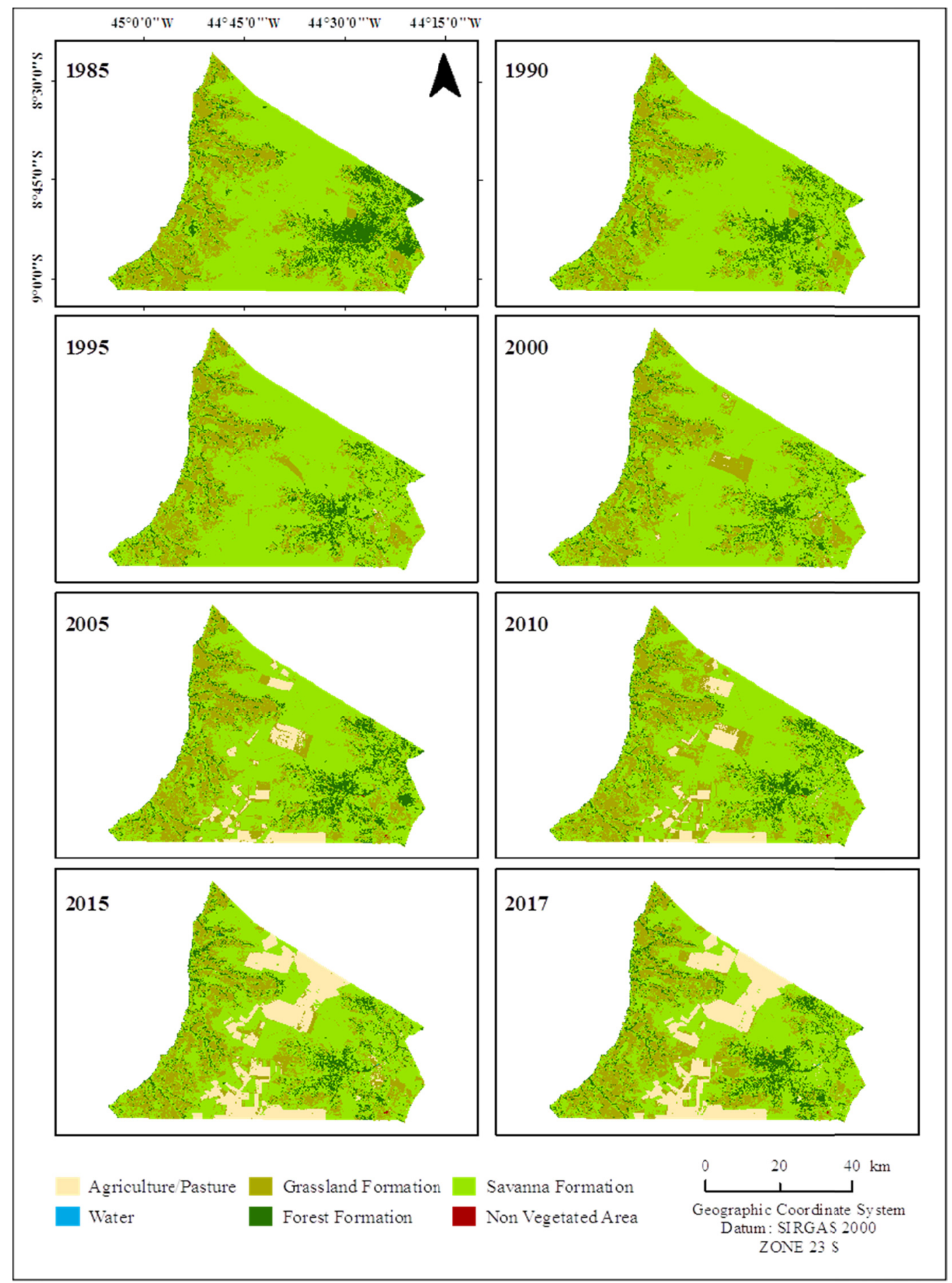

Figure 4. Spatial-temporal dynamic of land cover changes in the county of Currais, Piauí, Brazil, in a time series of 32 years (1985 to 2017)

This trend has also been observed in areas adjacent to Currais. For example, Santos et al. (2017) reported a loss of $54.81 \%$ of native vegetation and an increase of $297.98 \%$ of exposed soil between 1984 and 2015 in southwestern Piauí. França et al. (2016) pointed out an increase of 55\% in the occupation of crops between 1984 and 2011 in a sub-basin of the Uruçuí-Preto river, also in southwestern Piauí.

The accelerated use and occupation of the Cerrado in Piauí from the 2000s are directly related to the decrease of lands in other regions of Brazil, the properties with low values in Piauí, the favorable soil characteristics (França 
et al., 2017), and the implementation of large projects for the production of grains, mainly soybeans for exportation (Aguiar \& Monteiro, 2005).

This expansion of agribusiness brought intense pressure on natural resources in the county of Currais, mainly by the conversion of areas of natural vegetation into agriculture and livestock areas. There is an urgent concern in maintaining these forests performing their ecosystem services, contributing to the maintenance of ecological functions, as well as guaranteeing the income of small rural producers and the human well-being in space and over time (Costanza et al., 2014; Mutoko et al., 2015). Some ecosystem services have already been lost and modified. Santos et al. (2017), studying the relationship between deforestation and climate change in the region, observed a reduction of $14.34 \mathrm{~mm}$ in the monthly average precipitation, totaling a rainfall of $172.08 \mathrm{~mm}^{-1} \mathrm{ear}^{-1}$, which increased the maximum temperature in $0.91{ }^{\circ} \mathrm{C}$ and decreased the relative air humidity in $7.43 \%$. These results were corroborated by Albuquerque and Lopes (2016), who reported that changes in vegetation cover have a significant influence on the variation of temperature and relative air humidity.

The grasslands suffered little changes in vegetation-cover over the 32 years (Table 2). This fact can be associated with the type of occupation of these areas, composed mostly by small properties of family farmers located on steep slopes and scarps, which are improper for agricultural mechanization and large scale projects. On the other hand, savannas and forests had the largest losses in hectares (41,663.73 and 9,837.35 ha, respectively). The total number of hectares used to agriculture or pasture in the year 2017 was 50,772.63 ha, approaching the grassland area in the same year $(75,047.37$ hectares) (Table 2).

Table 2. Dynamics of the area (ha) of land use and land cover in the county of Currais, Piauí, Brazil, from 1985 to 2017

\begin{tabular}{lllllll}
\hline Year/Class & Forest & Savanna & Grassland & Agriculture/Pasture & Non-vegetated & Water bodies \\
\hline 1985 & $41,931.88$ & $199,317.51$ & $74,326.96$ & 43.38 & 34.62 & 4.68 \\
1990 & $29,528.47$ & $224,311.80$ & $61,727.86$ & 59.1 & 31.62 & 0.44 \\
1995 & $25,144.42$ & $223,464.70$ & $66,817.91$ & 194.89 & 33.30 & 2.74 \\
2000 & $23,845.11$ & $216,576.47$ & $74,444.61$ & 726.93 & 46.99 & 18.29 \\
2005 & $31,992.32$ & $187,371.55$ & $78,556.48$ & $17,649.63$ & 62.45 & 26.51 \\
2010 & $26,323.97$ & $186,468.87$ & $83,656.46$ & $19,118.91$ & 69.60 & 20.15 \\
2015 & $26,341.36$ & $167,904.50$ & $71,796.25$ & $49,514.00$ & 87.27 & 14.58 \\
2017 & $32,094.53$ & $157,653.78$ & $75,047.37$ & $50,772.63$ & 73.14 & 16.53 \\
\hline
\end{tabular}

In this aspect, the knowledge of strategies to guide the use of natural resources in a sustainable way becomes urgent and indispensable. The Brazilian law of native vegetation protection (Law No. 12,651/2012), that establishes general norms on the preservation of forests (Brazil, 2012), together with the Law No. 9,985/2000, that establishes criteria for the creation of conservation units (Brazil, 2000), are essential instruments for the maintenance, conservation, and sustainable development of ecosystems. On the other hand, the lack of supervision and cohesive application of these environmental policies, as well as the lack of study with technical-scientific bases has prevented the directing of public plans for the conservation, preservation, and sustainable management of natural resources and soil in this region.

\section{Conclusion}

1). The land use and vegetation cover in the county of Currais, Piauí, suffered rapid changes between 1985 and 2017, with the increasing anthropic pressure on natural resources, mainly through the conversion of savannas and forests into agriculture or livestock areas.

2). The registered changes have affected the natural landscape with loss and modification of ecosystem services that are essential for the well-being of local and regional population.

3). The results are relevant for decision making and can be safely used to guide public policies for the conservation, monitoring, preservation, and sustainable management of the vegetation remnants.

\section{References}

Aguiar, T. J. A., Monteiro, M. S. L. (2005). Modelo agrícola e desenvolvimento sustentável: A ocupação do Cerrado Piauiense. Ambiente e Sociedade, 8, 1-18. https://doi.org/10.1590/S1414-753X2005000200009 
Albuquerque, M. M., \& Lopes, W. G. R. (2016). Influência da vegetação em variáveis climáticas: Estudo em bairros da cidade de Teresina, Piauí. Revista Ra'eGa, 36, 38-68. https://doi.org/10.5380/raega.v36i0.39719

Alvares, C. A., Stape, J. L., Sentelhas, P. C., Gonçalves, J. L. M., \& Sparovek, G. (2013). Köppen's climate classification map for Brazil. Meteorologische Zeitschrift, 22, 711-728. https://doi.org/10.1127/0941-2948/ 2013/0507

Benedetti, A. C. P., Lippert, D. B., Pereira, R. S., Almeida, C. M., Cardoso, C. D. V., \& Hendges, E. R. (2013). Uso do produto MOD13Q1 do sensor Modis para analise temporal e mapeamento das florestas nas Serras do Sudeste e Campanha Meridional do Rio Grande do Sul. Revista Árvore, 37(3), 459-467. https://doi.org/ 10.1590/S0100-67622013000300009

Borghi, E., Bortolon, L., Avanzi, J. C., Bortolon, E. S. O. ,Ummus, M. E., Gontijo Neto, M. M., \& Costa, R. V. (2014). Desafios das novas fronteiras agrícolas de produção de milho e sorgo no Brasil: desafios da região do MATOPIBA. In D. Karam, \& P. C. Magalhães (Eds.), Eficiência nas cadeias produtivas e o abastecimento global (pp. 263-278). Anais, Sete Lagoas: ABMS.

Botrel, R. T., Brito, D. R. S., Sousa, W. C., Souza, A. M., \& Holanda, A. C. (2015). Phenology of tree species in Caatinga/Cerrado boundary in Southern Piauí. Rev. Verde de Agroecologia e Desenvolvimento Sustentavel, 10(3), 7-12. https://doi.org/10.18378/rvads.v10i3.3587

Brasil. (2000). Lei Federal no. 9.985 de 18 de Julho de 2000. Institui o Sistema Nacional de Unidades de Conservação da Natureza (SNUC), Brasília, Brazil. Retrieved from http://www.planalto.gov.br/ccivil_03/ LEIS/L9985.htm

Brasil. (2004). Decreto $n^{\circ}$ 5.092, de 21 de Maio de 2004. Define regras para identificação de áreas prioritárias para conservação, Brasília, Brazil. Retrieved from http://www.planalto.gov.br/ccivil_03/_Ato2004-2006/ 2004/Decreto/D5092.htm

Brasil. (2012). Lei Federal $n^{o}$. 12.651, de 25 de Maio de 2012. Dispõe sobre a proteção da vegetação nativa, Brasília, Brazil. Retrieved from http://www.planalto.gov.br/ccivil_03/_ato2011-2014/2012/lei/112651.htm

Cepro, P. (1996). Caracterização do quadro natural (p. 116). Teresina, PI: Fundação CEPRO.

Costanza, R., De Groot, R., Sutton, P., Der Ploeg, S. V., Anderson, S. J., Kubiszewski, I., Farber, S., \& Turner, R. K. (2014). Changes in the global value of ecosystem services. Global Environmental Change, 26, 152-158. https://doi.org/10.1016/j.gloenvcha.2014.04.002

França, L. C. J., Silva, J. B. L., Lisboa, G. S., Lima, T. P., \& Ferraz, F. T. (2016). Elaboração da Carta de risco de contaminação por agrotóxicos para a bacia do Riacho da Estiva, Brasil. Floresta e Ambiente, 23(4) 463-474. https://doi.org/10.1590/2179-8087.141415

França, L. C. J., Ribeiro, N. M. A. R., Santos, E. L., Noronha, F. C. C., Santos, E. L., \& Ribeiro, A. T. (2017). Caracterização da cobertura vegetal e uso do solo no município de Uruçuí, Piauí, Brasil. Nativa, 5, $337-341$. https://doi.org/10.5935/2318-7670.v05n05a06

França, L. C. J., Silva, J. B. L., Lisboa, G. S., Mucida, D. P., Cerqueira, C. L., \& Santos, E. L. (2018). Análise espaço-temporal da cobertura vegetal em uma bacia hidrográfica na região do MATOPIBA, Brasil. Nativa, 6, 737-744. https://doi.org/10.31413/nativa.v6i0.5843

Ibge. Censo demográfico (2000). Características da população e dos domicílios. Rio de Janeiro: IBGE. Retrieved from https://ww2.ibge.gov.br/home/estatistica/populacao/censo2000

Mapbiomas. (2019). Coleção [versão 3.0] da Série Anual de Mapas de Cobertura e Uso de Solo do Brasil. Retrieved from http://mapbiomas.org

Mittermeier, R. A., Turner, W. R., Larsen, F. W., Brooks, T. M., \& Gascon, C. (2011). Global Biodiversity Conservation: The Critical Role of Hotspots. In F. E. Zachos, \& J. C. Habel (Eds.), Biodiversity Hotspots: Distribution and Protection of Conservation Priority Areas (pp. 3-22). Berlin Heidelberg: Springer-Verlag. https://doi.org/10.1007/978-3-642-20992-5_1

Mutoko, M. C., Hein, L., \& Shisanya, C. A. (2015). Tropical forest conservation versus conversion trade-offs: Insight from analysis of ecosystem services provided by Kakamega rainforest in Kenya. Ecosystem Services, 14, 1-11. https://doi.org/10.1016/j.ecoser.2015.03.003

Pragana, R. B., Ribeiro, M. R., Nóbrega, J. C. A., Ribeiro Filho, M. R., \& Costa, J. A. (2012). Qualidade física de Latossolos Amarelos sob plantio direto na região do cerrado piauiense. Revista Brasileira de Ciência Solo, 36(5), 1591-1600. https://doi.org/10.1590/S0100-06832012000500023 
Reydon, B. P., \& Monteiro, M. S. L. (2009). A ocupação do cerrado piauiense: Um processo de valorização fundiária. Retrieved from http://www.sober.org.br/palestra

Ribeiro, J. F., \& Walter, B. M. T. (2008). As principais fitofisionomias do bioma Cerrado. In S. M. Sano, S. P. Almeida, \& J. P. Ribeiro (Eds.), Cerrado: Ecologia e flora. Planaltina: Embrapa.

Santos, J. C., Lisboa, G. S., França, L. C. J., Stepka, T. F., Silva, J. B. L., Miranda, D. L. C., \& Cerqueira, C. L. (2017). Relação entre variáveis meteorológicas e o uso e cobertura do solo no Sudoeste do Piauí, Brasil. Nativa, 5, 414-420. https://doi.org/10.5935/2318-7670.v05n06a06

Silva, E. A., Pereira, R. S., Silva, C. K., Goergen, L. C. G., \& Schuh, M. S. (2014). Uso de imagens orbitais no geoprocessamento algébrico da microrregião da Campanha Ocidental, Rio Grande do Sul. Revista Floresta e Ambiente, 21(3), 277-285. https://doi.org/10.1590/2179-8087.069013

Silva, J. B. L., Ferreira, W. L., Almeida, K. N. S., Souza, K. B., \& Nobrega, J. C. A. (2014). Evolução temporal do desmatamento e expansão agrícola entre 1984 a 2010 na sub-bacia do Rio Uruçuí-Preto, Piauí. Engenharia na Agricultura, 22(3) 254-261. https://doi.org/10.13083/1414-3984.v22n03a08

Sloan, S., Jenkins, C. N., Lucas N., Joppa, L. N., Gaveau, D. L. A., \& Laurance, W. F. (2014). Remaining natural vegetation in the global biodiversity hotspots, Biological Conservation, 177, 12-24. https://doi.org/ 10.1016/j.biocon.2014.05.027

Vaeza, R. F., Filho, P. C. O., Maia, A. G., \& Disperati, A. A. (2010). Uso e cobertura do solo em bacia hidrográfica urbana a partir de imagens orbitais de alta resolução. Floresta e Ambiente, 17, 23-29. https://doi.org/10.4322/floram.2011.003

\section{Copyrights}

Copyright for this article is retained by the author(s), with first publication rights granted to the journal.

This is an open-access article distributed under the terms and conditions of the Creative Commons Attribution license (http://creativecommons.org/licenses/by/4.0/). 